\title{
CIRI-CIRI FANTASTIK DUA CERITA RAKYAT KALIMANTAN DALAM BUKU KUMPULAN CERITA RAKYAT NUSANTARA KARYA KIDH HIDAYAT
}

\author{
Indrawan Dwisetya Suhendi \\ Universitas Pendidikan Indonesia \\ Pos-el: dwisetyaindrawan@yahoo.com
}

\begin{abstract}
Abstrak
Tulisan ini mencoba untuk mengungkap ciri-ciri fantastik dua cerita rakyat Kalimantan dalam buku Kumpulan Cerita Rakyat Nusantara (KCRN) karya Kidh Hidayat. Seperti judul buku tersebut, cerita ini memang berasal dari cerita lisan yang kemudian dituliskan untuk lebih dikenal luas di kalangan pembaca. Data yang tersedia dalam buku ini berupa cerita rakyat Kalimantan yang berjudul Asal Mula Hantu Jadi-jadian Hantuen (AMHJH) dan Asal Mula Burung Roak (AMBR). Metode yang digunakan dalam penelitian ini adalah metode deskriptif. Di mana data yang berupa teks cerita akan dideskripsikan menurut struktur cerita fantastik Raymond Rogé untuk kemudian dilihat ciri-ciri kefantastikkan yang dimilikinya. Dalam tulisan ini, akan dibahas mengenai (1) struktur cerita AMHJ dan AMBR, dan (2) ciriciri fantastik dalam kedua cerita tersebut.
\end{abstract}

Kata kunci: cerita fantastik, cerita rakyat kalimantan

THE CHARACTERISTICS OF TWO FANTASTIC STORIES IN KUMPULAN CERITA RAKYAT NUSANTARA (KCRN) BY KIDH HIDAYAT

\begin{abstract}
This paper attempts to uncover the characteristics of two fantastic stories in Kumpulan Cerita Rakyat Nusantara (KCRN) by Kidh Hidayat. As the title of the book implies, this story is derived from the oral stories that were later written in order to be more widely known among readers. The data are in the form of the tradisional prose entitled Asal Mula Hantu Jadijadian Hantuen (AMHJH) and Asal Mula Burung Roak (AMBR). The method used in this research is a descriptive method. The data will be described according to Raymond Rogé's fantastic story structure and their fantastic features will be examined. In this paper, the following will be laid out: (1) the structure of AMBR and AMHJ stories, and (2) the characteristics of the fantastic features in the two stories.
\end{abstract}

Keywords: fantastic story, Kalimantan tradisional prose

\section{PENDAHULUAN}

Nusantara yang terbentang luas dari ujung pulau Sumatera sampai Papua menyimpan pesona budaya yang tidak terkira. Budaya yang dihasilkan dari kearifan lokal tersebut tumbuh subur di Nusantara. Berbagai rona budaya tersebut ada yang bersifat lisan maupun bukan lisan. Kebudayaan tersebut kini sangat diminati oleh para sarjana untuk mengungkap banyak nilai yang tersembunyi dalam kebudayaan tersebut. Untuk mengungkapnya diperlukanlah pisau analisis yang tepat. Salah satu pisau analisis tersebut ialah folklor. Folklor adalah salah satu cabang keilmuan yang kini mulai mapan dan berhasil mencuri minat para peneliti dewasa ini. Folklor sebagai sebuah ilmu yang mencoba mengungkap makna dari hasilhasil kebudayaan tersebut mulai dipelajari 
di perguruan-perguruan tinggi di Indonesia. Danandjaja dalam Folklor Indonesia-nya berhasil merumuskan pengertian folklor sebagai kebudayaan suatu kolektif yang tersebar dan diwariskan turun-temurun (Danandjaja, 2007:2). Folklor dipilah berdasarkan jenisnya menjadi 1) folklor lisan, 2) folklor sebagian lisan, dan 3) folklor bukan lisan. Kata lisan menjadi begitu penting dalam folklor karena kelisanan umumnya sudah dikenal masyarakat jauh sebelum ditemukannya aksara. Hasil kebudayaan kelisanan itulah yang kini banyak diungkap para pakar untuk mendapatkan kearifan lokal dan nilainilai luhur yang masih relevan dengan keadaan kekinian. Salah satu hasil budaya kelisanan itu adalah cerita rakyat. Cerita rakyat adalah salah satu jenis folklor lisan yang paling banyak mendapat perhatian para pakar. Berbagai kajian tentang cerita rakyat banyak memunculkan teori-teori, sebut saja naratologi Propp dan LeviStrauss. Berbagai pendekatan pun banyak dilakukan untuk mengungkapkan jati diri cerita rakyat seterang-terangnya, termasuk ciri-ciri fantastik yang terkandung dalam cerita rakyat tersebut.

Claude Puzin mengatakan bahwa cerita fantastik adalah cerita yang mengandung peristiwa atau sesuatu yang diciptakan oleh imajinasi, tidak terdapat di dunia nyata, ceritanya sangat tidak mungkin terjadi (Puzin, 1984:3 dalam Ariani, 2007:1). Pakar lain yang menaruh perhatian terhadap cerita fantastik adalah Raymond Rogé. Rogé mengatakan bahwa cerita fantastik adalah cerita yang lebih menekankan ketakutan pembaca (Rogé, 1977:9-10 dalam Arini, 2007:2). Todorov kembali memberikan syarat cerita fantastik yaitu memberikan keraguan terhadap pembaca. Todorov mengatakan "keraguan pembaca adalah syarat utama cerita fantastik" (Todorov, 1970:11-12 dalam Ariani, 2007:9). Sedangkan pakar dari Indonesia yakni Apsanti Djokosujatno mengatakan bahwa cerita fantastik adalah cerita menyangkut dunia "riil" dan "rasional" yang dikejuti oleh kilasan-kilasan peristiwa takriil atau supranatural (Djokosujatno, 2001:vii). Penelitian tentang ciri-ciri fantastik tentu sangat mungkin diterapkan dalam cerita rakyat karena sifatnya yang pralogis. Dalam cerita rakyat Nusantara, kefantastikkan sangat mudah ditemukan, tapi sayangnya penelitian tentang hal itu masih sangat sulit ditemukan. Oleh sebab itulah, peneliti merasa tertantang untuk melakukan penelitian tentang ciri-ciri fantastik dalam cerita rakyat yang dalam penelitian kali ini adalah cerita rakyat Kalimantan.

Adapun tujuan dari penelitian ini adalah untuk mengetahui struktur cerita rakyat Kalimantan yang terdapat dalam buku Kumpulan Cerita Rakyat Nusantara (KCRN) karya Kidh Hidayat yang terbit tahun 1999 dan diterbitkan oleh CV. Pustaka Agung Harapan lalu mengungkap ciri-ciri fantastik dalam cerita rakyat Kalimantan terebut.

Teori-teori yang digunakan dalam penelitian ini adalah teori struktural Tzvetan Todorov untuk mengupas aspek kesastraan cerita rakyat Kalimantan. Todorov mengatakan telaah sastra dikelompokkan ke dalam tiga bagian: menurut aspek verbal, sintaksis, dan semantik teks (Todorov, 1985:12). Untuk melihat aspek kefantastikkan cerita rakyat Kalimantan digunakan teori Raymond Rogé mengenai struktur cerita fantastik. Rogé (1977:11-12 dalam Ariani, 2007:9) mengatakan suatu cerita fantastik memiliki struktur sebagai berikut:

\section{Ambition $\longrightarrow$ Avertissement $\longrightarrow$ Transgression $\longrightarrow$ Malédiction \\ Keinginan $\longleftrightarrow$ Peringatan $\longrightarrow$ Pelanggaran $\longrightarrow$ Kutukan/hukuman}


a. Ambition merupakan keinginan tokoh untuk mendapatkan atau melakukan sesuatu. Tahap ini diawali dengan entrées (situasi awal) yang berisi pengenalan tokoh dan situasi awal cerita.

b. Avertissement merupakan peringatan yang diberikan kepada tokoh. Namun, tokoh cenderung mengabaikan peringatan-peringatan yang ada.

c. Transgression merupakan pelanggaran yang dilakukan oleh tokoh terhadap peringatan yang telah diberikan. Akibat keingintahuan, kekuatan dan kekayaannya, tokoh melakukan hal yang dilarang dan melanggar batas kekuatan yang lebih besar darinya.

d. Malediction merupakan kutukan atau nasib buruk yang dialami oleh tokoh. Nasib buruk ini didapat melalui berbagai hal, seperti kutukan turun temurun (seperti kutukan keluarga), kemalangan akibat suatu hal yang ditularkan (seperti gigitan vampir), dan lain-lain. Cerita fantastik biasanya berakhir dengan kutukan ataupun kematian tokoh (Ariani, 2007:9-10).

\section{METODE}

Dalam penelitian ini, metode yang digunakan adalah metode deskriptifkualitatif. Data kualitatif yang berupa dua cerita rakyat berjudul Asal Mula Hantu Jadi-jadian Hantuen (AMHJH) dan Asal Mula Burung Roak (AMBR) dideskripsikan secara struktur menurut teori struktural Todorov untuk mengungkap aspek kesastraan dari kedua cerita tersebut. Sedangkan teori struktur cerita fantastik Rogé digunakan untuk mendeskripsikan ciri-ciri fantastik yang terdapat dalam cerita tersebut.

\section{HASIL DAN PEMBAHASAN}

Hasil penelitian ini berupa dua teks cerita rakyat Kalimantan. Teks pertama berjudul Asal Mula Hantu Jadi-jadian Hantuen (AMHJH), sedangkan teks cerita kedua bejudul Asal Mula Burung Roak
(AMBR). Kedua teks cerita tersebut terdapat dalam buku Kumpulan Cerita Rakyat Nusantara (KCRN) karya Kidh Hidayat.

Pembahasan dalam tulisan ini akan dibagi menjadi beberapa subpembahasan. Sub pertama, kedua teks cerita rakyat ini dianalisis aspek kesastraannya melalui teori struktural Todorov. Subpembahasan kedua, kedua teks cerita rakyat akan dianalisis ciri fantastiknya melalui teori struktur cerita fantastik Rogé.

\section{Analisis Aspek Kesastraan Dua Cerita Rakyat Kalimantan}

Analisis aspek kesastraan dua cerita rakyat Kalimantan didasarkan kepada teori struktural Todorov terhadap karya sastra. Sebagaimana dalam pendahuluan, telah disebutkan teori tentang analisis terhadap teks sastra. Todorov mengatakan telaah sastra dikelompokkan ke dalam tiga bagian: menurut aspek verbal, sintaksis, dan semantik teks (Todorov, 1985:12). Namun, dalam tulisan ini, analisis hanya difokuskan pada aspek sintaksis dan semantik teks, karena teks cerita rakyat tidak sekompleks teks cerita rekaan. Cerita rakyat pada dasarnya merupakan cerita lisan sehingga tidak sekompleks cerita rekaan.

\section{1) Struktur Cerita Asal Mula Hantu Jadi- jadian Hantuen (AMHJH)}

a. Analisis Aspek Sintaksis Asal Mula Hantu Jadi-jadian Hantuen (AMHJH)

Analisis aspek sintaksis dalam AMHJH berusaha menguraikan alur teks cerita. Alur teks cerita AMHJH didapat melalui analisis fungsi utama. Sebelum mengungkap alur cerita AMHJH, terlebih dahulu akan disajikan fungsi-fungsi utama yang nanti akan disusun berdasarkan hubungan kausalitasnya sehingga akan terjalin alur yang utuh. Berikut adalah fungsi-fungsi utama dalam AMHJH.

1) Peristiwa mandinya Tapih di sungai (Fungsi utama pertama penggerak cerita); 
2) Peristiwa tertiupnya topi sakral milik Tapih yang kemudian hanyut terbawa derasnya arus sungai;

3) Kepergian Tapih dan orang tuanya untuk mencari topi sakral yang hilang tersebut;

4) Peristiwa ditemukannya topi Tapih oleh seorang pemuda bernama Antang Taung;

5) Pemberian emas oleh kedua orang tua Tapih untuk Antang Taung sebagai imbalan telah menemukan topi Tapih, namun emas itu ditolak, sebagai gantinya Antang Taung meminta Tapih menjadi istrinya;

6) Disetujuinya persyaratan dari Antang Taung untuk memperistri Tapih dan berlangsunglah penikahan keduanya;

7) Berlakunya adat untuk pengantin baru yaitu kedua mempelai harus berdiam di rumah kedua orang tua masing-masing secara bergiliran;

8) Pembuatan jalan yang menghubungkan kedua desa orang tua mempelai masingmasing;

9) Munculnya makhluk gaib yang selalu mencuri makanan para pekerja pembuat jalan;

10) Tindakan para pekerja yang berusaha menangkap makhluk gaib tersebut;

11) Tertangkapnya makhluk gaib tersebut yang ternyata seekor angkes (hewan sejenis landak) yang kemudian berubah menjadi seorang pemuda;

12) Permohonan maaf pemuda jelmaan angkes tersebut dan berjanji untuk membantu pekerjaan para pembuat jalan;

13) Kesuksesan pemuda tersebut membuat jalan dalam waktu tiga hari berkat kesaktiannya;

14) Diangkatnya pemuda tersebut menjadi anak Tapih dan Antang Taung;

15) Tapih mengandung dan mengidam makan ikan kali;

16) Antang Taung mencari ikan kali, namun hujan lebat membuat seekor ikan tomang hasil tangkapan Antang Taung tertinggal dalam biduk;
17) Kembalinya Antang Taung ke biduknya untuk mengambil ikan yang tertinggal, tapi ternyata ikan tersebut berubah menjadi seorang bayi perempuan, lalu bayi tersebut diangkat menjadi anak;

18) Keanehan pada bayi perempuan tersebut yang tumbuh dengan cepat menjadi gadis dewasa;

19) Hubungan cinta antara laki-laki jelmaan angkes dengan perempuan jelmaan ikan;

20) Pernikahan antara laki-laki jelmaan angkes dengan perempuan jelmaan ikan;

21) Kelahiran seorang anak laki-laki dari pasangan laki-laki jelmaan angkes dengan perempuan jelmaan ikan, namun anak itu meninggal setelah dilahirkan;

22) Kelahiran bayi Tapih dan Antang Taung namun anak itu meninggal sesaat setelah lahir;

23) Adat setempat yang mengharuskan orang yang meninggal harus dilakukan dua kali upacara kematian, pada upacara pertama dilakukan upacara penguburan, upacara kedua tulang-belulang dibakar (tiwah);

24) Pelaksaan upacara kedua (tiwah) terhadap tulang-belulang anak Tapih dan Antang Taung;

25) Rencana pasangan laki-laki jelmaan angkes dengan perempuan jelmaan ikan untuk ikut bersama melaksanakan upacara tiwah;

26) Penolakan Tapih dan Antang Taung terhadap rencana anak angkatnya;

27) Perbuatan pasangan laki-laki jelmaan angkes dengan perempuan jelmaan ikan yang bersikukuh untuk ikut melaksanakan tiwah;

28) Penggalian tulang belulang anak pasangan laki-laki jelmaan angkes dengan perempuan jelmaan ikan yang ternyata di dalamnya berisi tulangbelulang hewan dan ikan, yang membuat kedua pasangan ini menjadi malu;

29) Mengungsinya kedua pasangan laki-laki jelmaan angkes dengan perempuan jelmaan ikan tersebut ke Desa Sepang 
Simin dan mereka membangun desa di tengah hutan;

30) Berkembangnya keturunan pasangan laki-laki jelmaan angkes dengan perempuan jelmaan ikan menjadi

hantuen (makhluk jadi-jadian).

Berikut adalah bagan alur cerita AMHJH.

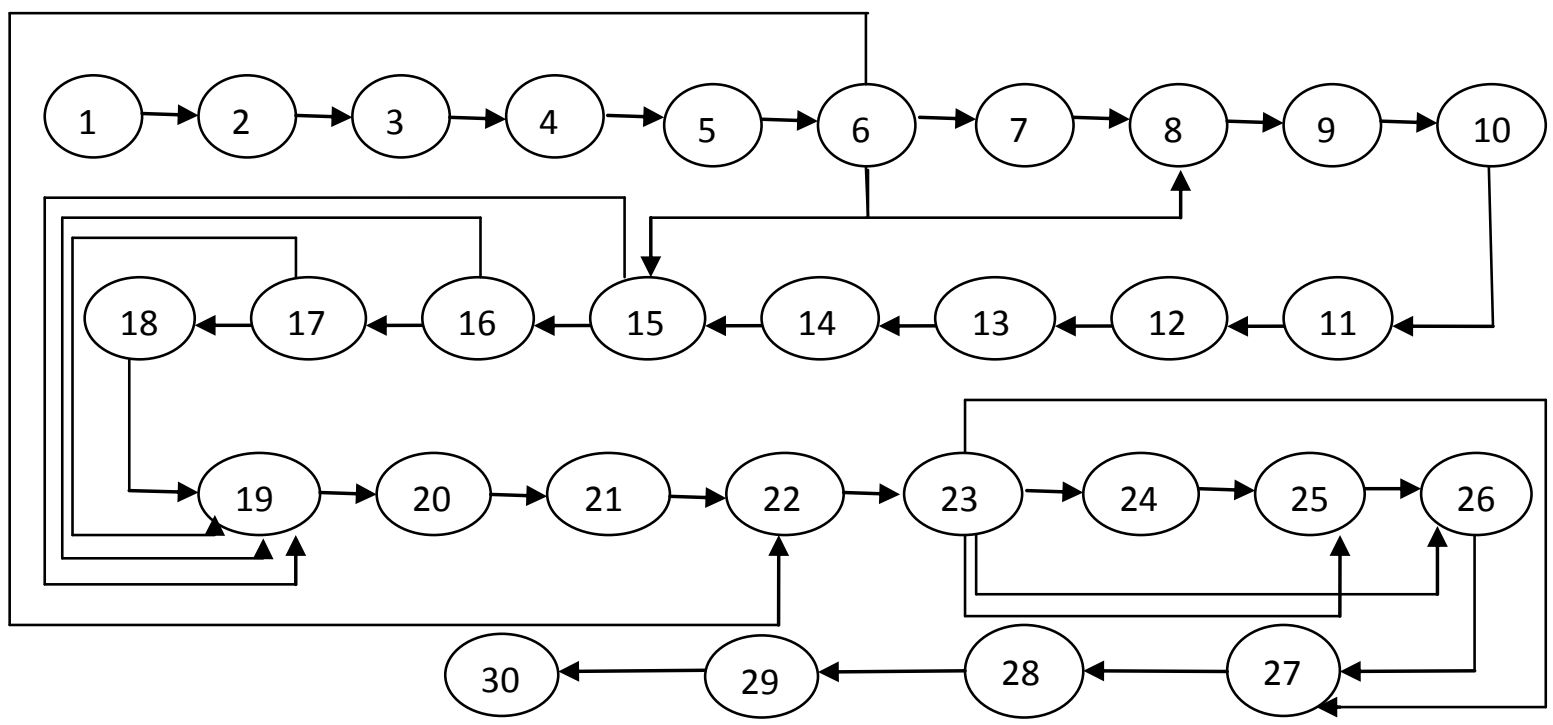

Bagan 1 Alur Cerita AMHJH

Bagan alur di atas menunjukkan adanya kausalitas antara tiap-tiap fungsi utama. Fungsi utama satu merupakan fungsi utama pertama penggerak cerita. Bila fungsi utama satu tidak ada, maka alur tidak akan terjalin dengan harmonis. Bagan di atas menunjukkan alur yang runut dan cenderung bergerak maju.

\section{b. Analisis Aspek Semantik Asal Mula Hantu Jadi-jadian Hantuen (AMHJH)}

Analisis aspek semantik berusaha untuk menunjukkan tokoh dan latar dalam teks cerita ini. Analisis tokoh dan latar merupakan analisis aspek semantik dalam teks naratif sebagaimana pendapat Zaimar (2008:336). Menurut Zaimar dalam aspek semantik teks naratif terdapat tokoh dan gagasan, hal ini juga senada dengan Durachman (1996:40) yang dalam tesisnya menyebutkan bahwa analisis tokoh dan latar sangatlah penting karena analisis tokoh dan latar dapat mengisyaratkan pemikiran tertentu. Berikut adalah analisis tokoh dan latar AMHJH.

\section{c. Analisis Tokoh Asal Mula Hantu Jadi- jadian Hantuen (AMHJH)}

Dalam teks cerita AMHJH, terdapat empat orang tokoh yang memegang peranan dalam cerita. Kelima tokoh tersebut adalah Tapih, Antang Taung, Lelaki jelmaan Angkes, dan perempuan jelmaan ikan. Berikut adalah analisis tokoh cerita AMHJH.

Tapih adalah seorang anak gadis sebuah keluarga pembuat keranjang rotan dan topi tanggul dareh. Topi tersebut digunakan untuk upacara memandikan bayi di sungai. Secara fisik, ada beberapa kutipan yang menggambarkan keadaan fisik Tapih seperti berikut ini.

Tapih merupakan seorang anak gadis yang cantik sekali. Kulitnya berwarna putih kekuning-kuningan dan rambutnya yang panjang berwarna hitam pekat (Hidayat, 1999: 76).

Kutipan tersebut menunjukkan kecantikan sebagai ciri fisik Tapih. Secara psikis, tidak ada kutipan dalam teks yang 
menjelaskan ciri-ciri psikis yang dimiliki Tapih, tapi lewat beberapa petunjuk dalam teks didapatlah penggambaran Tapih secara psikis. Secara psikis Tapih adalah perempuan yang sabar dan bertanggung jawab. Hal ini terlihat dari kesabarannya dalam mencari topi yang terbang tertiup angin ketika ia mandi di sungai. Tanpa pernah lelah ia terus berusaha mencari topi tersebut. Kemudian rasa bertanggungjawabnyalah yang membuat ia mau menerima Antang Taung sebagai suaminya kerena Antang Taunglah yang telah menemukan topinya. Selain itu, Tapih adalah perempuan yang menjunjung tinggi adat. Hal itu dapat terlihat saat Tapih melaksanakan adat yang mengharuskannya untuk berdiam di rumah orang tua dan mertuannya secara bergantian. Tapih merupakan tokoh utama yang menggerakkan cerita. Tapih adalah tokoh protagonis, pipih, riil, dan individual. Sebagai tokoh pipih, Tapih hanya dipandang dalam satu sisi oleh narator. Tokoh riil kerena Tapih memang ada dan hidup secara nyata pada cerita. Individual karena sosok Tapih hanya sendiri dan bukan tokoh kelompok.

Antang Taung adalah suami dari Tapih. Ia dikenalkan dalam cerita ketika ia menemukan topi Tapih yang terbawa angin dan menyerahkannya kepada Tapih. Awalnya orang tua Tapih bermaksud memberikan emas kepada Antang Taung sebagi imbalan telah menemukan topi milik Tapih, namun Antang Taung menolak dan meminta Tapih menjadi istrinya. Permintaan itu dituruti dan menikahlah mereka berdua. Secara fisik dan psikis memang tidak terdapat secara langsung dalam teks. Namun melalui eksplorasi teks, peneliti mendapatkan gambaran sosok dan psikis tokoh. Sosok Antang Taung disebutkan adalah seorang pemuda. Tentu seorang pemuda adalah lelaki yang masih muda. Psikis tokoh menggambarkan bahwa Antang Taung adalah tokoh yang sangat mencintai istrinya dan menjunjung tinggi adat. Hal ini terbukti dari tindakan Antang Taung yang rela menjalani adat untuk bergantian tinggal di rumah kedua orang tua dan mertuanya secara bergantian lalu tindakan Antang Taung yang mencari ikan untuk memenuhi keinginan dari istrinya yang tengah mengandung anak mereka. Antang Taung adalah tokoh riil, individual, dan pipih. Sebagai tokoh riil, Antang Taung memang terdapat dalam cerita dan bukan sebagai tokoh simbolis. Keindividualan tokoh Antang Taung juga terlihat dari tokoh yang diberi nama oleh pencerita hal ini menunjukkan bahwa Antang Taung adalah tokoh individual. Disebut tokoh pipih karena Antang Taung dikenalkan hanya dari satu sudut pandang dan dari satu sisi.

Lelaki jelmaan angkes. Tokoh ini diceritakan pertama kali saat Tapih dan Antang Taung membuat jalan yang menghubungkan kedua desa masingmasing. Tokoh ini diceritakan sebagai tokoh yang kerap mengganggu para pekerja pembuat jalan dengan mencuri makanan mereka. Akhirnya ia berhasil ditangkap lalu diangkat sebagai anak oleh Tapih dan suaminya. Secara fisik terdapat sedikit kutipan yang menjelaskan fisik tokoh ini.

Setelah masuk ke dalam, binatang itu menggoyang-goyangkan tubuhnya, dan secara ajaib berubah menjadi seorang pemuda yang tampan (Hidayat, 1999: 78).

Secara psikis, hanya dua sifat yang secara tidak langsung tampak dalam teks, yakni keras kepala dan jail. Kekeraskepalaan tokoh ini tampak saat ia bermaksud membakar jasad anaknya dalam upacara tiwah bersama jasad anak Tapih dan suaminya. Tapih dan suaminya menolak rencana tersebut, tapi tokoh ini bersikukuh untuk melaksanakan tiwah. Kejailan tokoh ini terlihat saat tokoh ini masih berupa angkes. Hewan ini kerap mencuri bekal para pekerja pembuat jalan. Tokoh ini merupakan tokoh riil, individual, dan pipih. Disebut tokoh riil karena dalam cerita, tokoh ini ada dan ikut berperan dalam cerita. Individual karena tokoh ini 
sendiri dan tidak berkelompok dalam cerita. Tokoh pipih karena hanya diceritakan dalam satu sudut pandang pencerita.

Perempuan jelmaan ikan. Tokoh ini pertama dikenalkan saat Tapih meminta suaminya untuk mencari ikan kali. Tokoh ini adalah jelmaan salah satu ikan yang tertinggal dalam perahu Antang Taung. Tokoh ini memiliki kesaktian sehingga dalam waktu singkat tokoh ini menjelma menjadi seorang gadis. Secara fisik, tokoh ini digambarkan secara sekilas dalam teks.

Dalam waktu beberapa bulan saja ia sudah tumbuh menjadi seorang gadis dewasa yang sangat cantik dan molek (Hidayat, 1999: 79).

Secara psikis, sifat dari tokoh ini adalah keras kepala seperti suaminya lelaki jelmaan angkes. Ia bersikukuh untuk ikut melaksanakan upacara tiwas walau ditentang oleh kedua orang tua angkatnya. Tokoh ini merupakan tokoh riil, individual, dan pipih. Disebut tokoh riil kerena tokoh ini ada dan berkontribusi dalam menjalankan alur cerita. Individual karena tokoh ini sendiri dalam menjalankan cerita dan tokoh pipih karena diceritakan lewat satu sudut pandang.

\section{d. Analisis Latar Asal Mula Hantu Jadi- jadian Hantuen (AMHJH)}

Dalam cerita ini, terdapat beberapa latar tempat yang dapat diacu dan beberapa tempat bahkan dapat ditemui di Kalimantan. Hal ini karena cerita ini merupakan legenda yang oleh masyarakat pendukungnya dianggap benar-benar terjadi. Sisa-sisa dari legenda ini dapat dilihat di beberapa tempat di Kalimantan. Untuk analisis latar waktu, peneliti tidak menemukan satu pun acuan latar waktu. Pencerita hanya berkata dahulu kala, pada suatu ketika, keesokan harinya, frasa-frasa ini memang menunjukkan latar waktu, tetapi tidak merujuk pada waktu yang lebih spesifik. Jadi, dalam analisis latar ini, analisis akan terfokus pada latar tempat yang memang banyak disebut dalam teks cerita ini. Tempat pertama yang menjadi latar dalam teks ini adalah sebuah desa bernama Baras Semanyang, desa ini adalah desa di mana kedua orang tua Tapih dan Tapih tinggal. Di desa ini terdapat sungai yang sering dipakai Tapih untuk mandi, dan di sungai inilah topi Tapih tertiup angin sampai di Desa Sepang Simin yang merupakan desa dari Antang Taung. Kedua desa ini dapat ditemui di daerah Kalimantan Timur. Bahkan, ada jalan yang menghubungkan kedua desa ini yang konon dibuat oleh lelaki jelmaan angkes tersebut. Jalan itu kini bernama Jalan Lengkuas. Latar tempat berikutnya adalah tempat yang berkaitan dengan religiusitas orang Dayak Ngaju yaitu Lewu Tatau. Lewu Tatau adalah surga dalam kepercayaan Dayak Ngaju. Tempat ini adalah tempat kembalinya ruh setelah mengalami dua kali upacara penguburan.

\section{2) Struktur Cerita Asal Mula Burung Roak (AMBR)}

\section{a. Analisis Aspek Sintaksis Asal Mula Burung Roak (AMBR)}

Seperti pada cerita AMHJH, dalam analisis aspek sintaksis cerita AMBR terlebih dahulu akan disajikan fungsi-fungsi utama yang nanti akan disusun berdasarkan hubungan kausalitasnya sehingga akan terjalin alur yang utuh. Berikut adalah fungsi-fungsi utama dalam AMBR.

1) Didikan orang tua tokoh suami yang memanjakannya;

2) Sifat tokoh suami yang malas dan pemarah;

3) Jodoh yang mempertemukan kedua tokoh;

4) Pernikahan tokoh suami dan tokoh istri;

5) Tokoh istri mengandung dan melahirkan anaknya;

6) Sikap malas dan tidak bertanggung jawabnya tokoh suami yang semakin menjadi;

7) Perginya tokoh suami selama dua hari dari rumah;

8) Rasa jengkel tokoh istri terhadap kelakuan suaminya; 
9) Perbuatan tokoh istri memasak daging ari-ari anaknya untuk dihidangkan kepada suaminya;

10) Kepulangan tokoh suami ke rumahnya dan rasa lapar tokoh tersebut;

11) Tokoh suami memakan daging ari-ari anaknya dengan lahap;

12) Pertanyaan tokoh suami kepada istrinya tentang daging yang dimakannya;

13) Pengakuan tokoh istri bahwa masakan itu terbuat dari daging ari-ari anaknya;
14) Rasa mual pada tokoh suami;

15) Tokoh suami berusaha untuk memuntahkan daging ari-ari anaknya;

16) Kegagalan tokoh suami memuntahkan ari-ari anaknya;

17) Tokoh suami bersuara "Oaaak... Oaaaak...Oaaak" dan mulai tumbuh bulu lalu berubah menjadi burung roak.

Berikut adalah bagan alur AMBR.



Bagan 2 Alur AMBR

b. Analisis Aspek Semantik Asal Mula Burung Roak (AMBR)

Analisis aspek semantik cerita AMBR masih sama seperti pada cerita AMHJH yakni yang dianalisis adalah tokoh dan latar cerita AMBR.

\section{c. Analisis Tokoh Asal Mula Burung Roak (AMBR)}

Dalam AMBR terdapat dua tokoh utama yang mempunyai peran strategis dalam penceritaan. Kedua tokoh tersebut adalah Istri dan Suami. Berikut adalah analisis tokoh AMBR.

\section{Istri}

Tokoh ini tidak memiliki nama secara khusus, walau begitu tokoh ini adalah tokoh utama yang menjalankan fungsinya sebagai sosok sentral dalam cerita. Secara fisik, tidak ada satu pun keterangan dalam teks yang merujuk kepada penggambaran fisik tokoh ini. Berbeda dengan gambaran fisik tokoh, secara psikis banyak sekali rujukan dalam teks yang menggambarkan sifat tokoh istri. Tokoh istri digambarkan sangat rajin bekerja, hal ini merupakan buah dari didikan orang tuanya yang selalu mengajarinya untuk menjadi orang yang rajin sebab orang yang rajin hidupnya tidak akan mengalami kesulitan. Berikut adalah kutipan teks yang menjelaskan hal tersebut.

Sang istri adalah seorang wanita yang sangat rajin bekerja, itu memang sudah menjadi kebiasaannya sejak kecil. Ia selalu membantu orang tuanya bekerja di ladang. Orang tuanya selalu menasehati agar ia selalu rajin bekerja. Menurut orang tuanya, orang 
yang rajin bekerja itu hidupnya tidak akan mengalami kesulitan. Dan nasehat orang tuanya itu selalu diingatnya (Hidayat, 1999: 81).

Tokoh istri merupakan tokoh utama, protagonis, riil, individual, dan pipih. Keutamaan tokoh istri terlihat dari perannya yang cukup dominan dalam cerita. Ia merupakan tokoh sentral yang memiliki peran strategis dalam alur cerita. Tokoh ini juga merupakan tokoh protagonis karena tokoh ini memiliki sifat-sifat utama yang nanti akan beroposisi biner dengan suaminya yang antagonis. Tokoh ini juga merupakan tokoh riil karena memang ada, nyata, dan berperan aktif dalam penceritaan. Individual karena tokoh ini sendiri dan bukan kolektif. Tokoh ini merupakan tokoh pipih karena diceritakan dalam satu sudut pandang narator tanpa berusaha untuk mengungkap sisi lain dari tokoh ini.

\section{Suami}

Tokoh ini adalah oposisi biner dari sifat-sifat istrinya. Tokoh ini adalah tokoh yang bersifat pemalas, pemarah, dan tidak bertanggung jawab. Berikut adalah kutipan teks cerita yang menerangkan sifat tokoh ini.

...suami itu memiliki sifat-sifat tak terpuji. Suaminya seorang pemalas. Kerjanya setiap hari hanya mengobrol kesana-kemari dengan segala obrolan yang tak bermanfaat. Ia selalu bangun tidur jika matahari sudah tinggi. Sepulang dari kegiatan rutinnya yang mengobrol kesana-kemari, ia hanya tahu bahwa makanan dan minuman harus sudah tersedia. Jika istrinya terlambat menyediakan hidangan, ia menjadi marah-marah (Hidayat, 1999: 81).

Secara fisik, sama seperti tokoh sebelumnya, tokoh ini tidak digambarkan secara fisik dalam teks. Tokoh ini merupakan tokoh utama, antagonis, riil, individu, dan pipih. Tokoh ini merupakan tokoh utama karena perannya yang dominan dalam cerita. Tokoh ini juga merupakan tokoh antagonis dilihat dari sifatnya yang berlawanan dengan sifat istrinya. Tokoh ini merupakan tokoh riil karena tokoh ini ada, nyata, dan berperan dalam alur cerita. Tokoh individu karena tokoh ini bekerja sendiri dan tidak membawa kelompok atau kolektif apapun. Tokoh ini adalah tokoh pipih karena hanya diceritakan lewat satu sudut pandang narator.

\section{d. Analisis Latar Asal Mula Burung Roak (AMBR)}

Latar dalam cerita ini hanya berfokus pada latar tempat, sedangkan latar waktu tidak akan dibahas karena tidak ada satu pun teks yang merujuk pada latar waktu. Dalam teks ini terdapat latar tempat berupa sebuah desa bernama Desa Libau Kecamatan Sepauk. Desa inilah tempat segala peristiwa dalam cerita ini berlangsung. Desa Libau ini adalah nama desa yang sekarang, namun ketika peristiwa ini berlangsung mungkin nama desa ini bukan Libau. Berikut kutipan yang menunjukkan hal tersebut.

\section{Pada zaman dahulu di Desa Libau Kecamatan Sepauk (yang sekarang) hiduplah sepasang suami istri (Hidayat, 1999: 81).}

Latar tempat lainnya adalah Kalimantan Barat. Kalimantan Barat disebut sebagai tempat yang banyak terdapat burung roak. Kemudian tempat lainnya adalah tempat hidup burung roak yakni semak-semak berair.

\section{Analisis Aspek Kefantastikkan Dua Cerita Rakyat Kalimantan}

Setelah aspek kesastraan dengan menggunakan teori struktural Todorov berhasil digunakan pada dua cerita rakyat Kalimantan, analisis berikutnya yang menjadi fokus pembahasan dalam tulisan ini adalah analisis aspek kefantastikkan. Dalam analisis aspek kefantastikkan, teori yang 
digunakan adalah teori Raymond Rogé mengenai struktur cerita fantastik.

Setelah dianalisis lewat teori struktur cerita fantastik Rogé, dua cerita rakyat Kalimantan tersebut diungkap ciri-ciri fantastiknya lewat satuan-satuan peristiwa fantastik. Setelah dianalisis secara struktur cerita fantastik Rogé dan diungkap ciri fantastik dari cerita ini, maka terakhir dapat diketahui apakah dua cerita Kalimantan ini termasuk ke dalam cerita fantastik atau bukan.

\section{1) Analisis Struktur Cerita Fantastik Rogé terhadap Dua Cerita Rakyat Kalimantan}

Rogé (1977: 11-12 dalam Ariani, 2007:9) mengatakan suatu cerita fantastik memiliki struktur sebagai berikut:

\section{Ambition $\longleftrightarrow$ Avertissement $\longrightarrow$ Transgression $\longrightarrow$ Malédiction \\ Keinginan $\longleftrightarrow$ Peringatan $\Longrightarrow$ Pelanggaran $\longrightarrow$ Kutukan/hukuman}

a. Ambition merupakan keinginan tokoh untuk mendapatkan atau melakukan sesuatu. Tahap ini diawali dengan entrées (situasi awal) yang berisi pengenalan tokoh dan situasi awal cerita.

b. Avertissement merupakan peringatan yang diberikan kepada tokoh. Namun, tokoh cenderung mengabaikan peringatan-peringatan yang ada.

c. Transgression merupakan pelanggaran yang dilakukan oleh tokoh terhadap peringatan yang telah diberikan. Akibat keingintahuan, kekuatan, dan kekayaannya, tokoh melakukan hal yang dilarang dan melanggar batas kekuatan yang lebih besar darinya.

d. Malédiction merupakan kutukan atau nasib buruk yang dialami oleh tokoh. Nasib buruk ini didapat melalui berbagai hal, seperti kutukan turuntemurun (seperti kutukan keluarga), kemalangan akibat suatu hal yang ditularkan (seperti gigitan vampir), dan lain-lain. Cerita fantastik biasanya berakhir dengan kutukan ataupun kematian tokoh (Ariani, 2007:9-10). Berikut adalah analisis struktur cerita fantastik Rogé terhadap dua cerita rakyat Kalimantan.

\section{a. Analisis Struktur Cerita Fantastik Rogé terhadap AMHJH Ambition/Keinginan}

Dalam cerita AMHJH, tahap ini terlihat dari rencana pasangan laki-laki jelmaan angkes dengan perempuan jelmaan ikan untuk ikut bersama melaksanakan upacara tiwah (fungsi utama 25). Upacara tiwah adalah upacara yang harus dilalui agar ruh orang yang meninggal dapat menuju Lewu Tatau (surga orang Dayak Ngaju). Mulanya, pasangan Tapih dan Antang Taunglah yang bermaksud mengadakan upacara tiwah untuk menyempurnakan ruh anaknya yang meninggal. Ketika rencana ini didengar pasangan laki-laki jelmaan angkes dengan perempuan jelmaan ikan, mereka berencana untuk ikut serta melaksanakan tiwah. Berikut adalah kutipan dalam teks yang menjelaskan hal tersebut.

Ketika mendengar bahwa saudara angkatnya hendak ditiwahkan, suami istri jelmaan binatang itu ingin juga agar anaknya yang telah meninggal dibakar dalam upacara besar itu (Hidayat, 1999: 79).

\section{Avertissement/Peringatan}

Peringatan diberikan oleh Tapih dan Antang Taung mengenai rencana laki-laki jelmaan angkes dengan perempuan jelmaan ikan untuk ikut tiwah bersama anaknya 
yang meninggal. Tapih dan Antang Taung menolak rencana anak angkatnya tersebut tanpa disertai alasan. Inilah tahap peringatan dalam cerita ini. Peringatan ini terdapat dalam urutan fungsi utama ke-26. Berikut adalah kutipan teks untuk melihat hal tersebut.

Niat itu sangat ditentang oleh Tapih dan Antang Taung... (Hidayat, 1999: 79).

\section{Transgression/Pelanggaran}

Tahap berikutnya adalah transgression atau pelanggaran. Pelanggaran dilakukan oleh laki-laki jelmaan angkes dengan perempuan jelmaan ikan terhadap peringatan yang diberikan oleh Tapih dan Antang Taung. Kedua pasangan jelmaan binatang tersebut tetap bersikukuh untuk melaksanakan tiwah bersama saudara angkatnya. Peristiwa ini merupakan fungsi utama ke-27. Berikut adalah kutipan dalam teks cerita yang menjelaskan hal tersebut.

$$
\begin{aligned}
& \text {...tapi mereka tak menghiraukan dan } \\
& \text { bersikukuh dengan niatnya itu } \\
& \text { (Hidayat, 1999:79). }
\end{aligned}
$$

\section{Malédiction/Kutukan}

Tahap ini merupakan tahap akhir dalam struktur cerita fantastik Rogé. Dalam tahap ini, pelanggaran yang dilakukan oleh pasangan jelmaan binatang tersebut mendapat kutukan atau hukuman. Kutukan tersebut terlihat saat mereka menggali kuburan anaknya untuk ikut ditiwahkan bersama anak Tapih dan Antang Taung. Ternyata tulang belulang anaknya bukan tulang belulang manusia melainkan tulang binatang. Hal itu membuat mereka malu dan menyingkir ke tengah hutan dan membentuk keluarga Hantuen (hantu jadijadian). Inilah kutukan yang mereka terima sebagai konsekuensi akibat pelanggaran yang mereka lakukan. Peristiwa ini merupakan fungsi utama ke-28, 29, dan 30. Berikut adalah kutipan dalam teks untuk melihat hal tersebut.
Dan sesuatu yang menghebohkan terjadi, karena ketika jenazah anak suami istri manusia jadi-jadian digali dari kuburnya, ternyata yang tinggal bukan merupakan tulang belulang manusia melainkan tulang belulang binatang dan ikan. Kejadian itu membuat malu besar pada kedua suami istri asal binatang itu, sehingga akhirnya mereka menyingkir dari Desa Sepang Simin. Selanjutnya mereka membangun sebuah desa yang jauh di tengah-tengah hutan belantara (Hidayat, 1999: 79).

\section{2) Analisis Struktur Cerita Fantastik Rogé terhadap AMBR Ambition /Keinginan}

Dalam teks AMBR, tahap keinginan implisit dalam teks. Tahap ini berisi keinginan tokoh suami untuk menuruti segala nafsu atau hasrat dalam dirinya. Nafsu atau hasrat tersebut merupakan sifat malas dan tidak bertanggung jawab. Sifat tokoh suami tersebut merupakan sifat bawaan akibat terlalu dimanjakan oleh kedua orang tuanya. Bahkan saat tokoh suami telah menikah pun rasa malasnya tidak pernah berhenti bahkan semakin menjadi. Hasrat tokoh suami tersebut tercermin dalam kutipan teks berikut.

Sifat pemalas suaminya itu memang sudah dibawanya sejak kecil. Orang tuanya dulu selalu memanjakannya, terutama ibunya. Tak pernah ia disuruh melakukan pekerjaan setuatupun. Hal yang salah itu akhirnya terbiasa hingga ia menjadi orang dan berkeluarga (Hidayat, 1999: 81).

Meskipun sudah berkeluarga, tidak pernah terbesit sedikit pun pikiran tokoh suami untuk mengubah sifat pemalas tersebut. Inilah salah satu alasan bahwa memenuhi segala nafsu dan hasrat tokoh suami adalah merupakan tahap keinginan. 


\section{Avertissement/Peringatan}

Tahap peringatan adalah saat tokoh suami menikah dan kemudian isrtinya mengandung. Menikah dan memiliki anak seharusnya dijadikan peringatan oleh tokoh suami untuk mengubah sikapnya yang pemalas, mengingat ia sudah memiliki keluarga yang bergantung hidup padanya. Namun tokoh suami terus pada keinginannya untuk tetap menuruti nafsunya.

\section{Transgression/Pelanggaran}

Tahap pelanggaran terjadi saat tokoh istri tengah hamil tua lalu tokoh suami malah meninggalkan istrinya dengan alasan yang tidak jelas. Bahkan saat tokoh istri melahirkan anaknya, sang suami tidak pulang ke rumah. Berikut adalah kutipan dari hal tersebut.

Sembilan bulan kemudian, saat melahirkan pun tiba. Ketika istrinya melahirkan anaknya suaminya tidak ada di rumah. Sudah dua hari dua malam ia tidak pulang (Hidayat, 1999: 81).

\section{Malédiction/Kutukan}

Tahap kutukan terjadi saat tokoh suami memakan daging ari-ari anaknya yang dimasak oleh istrinya. Setelah tokoh suami memakan daging ari-ari tersebut, tokoh suami merasa mual, lalu suaranya menjadi “Oaaak!...Oaaak!...Oaaak!” dan terakhir timbul bulu lebat dan berubahlah tokoh suami menjadi burung Roak. Berikut adalah kutipan teks yang menjelaskan kutukan tersebut.

Tiba-tiba tubuh suami itu berubah menjadi seekor burung dan badannya mengecil. Burung jelmaan manusia itu kemudian terbang ke semak-semak. Dan sekarang burung itu dinamakan burung Roak (Hidayat,1999: 81).

\section{Satuan Peristiwa Fantastik dalam Dua Cerita Rakyat Kalimantan}

Setelah menelaah ciri fantastik dua cerita rakyat Kalimantan melalui analisis struktur cerita fantastik Rogé, sekarang marilah kita tengok satuan peristiwaperistiwa fantastik yang terkandung dalam kedua cerita rakyat Kalimantan berikut ini. Satuan cerita fantastik dianalisis berdasarkan pengertian cerita fantastik dari para ahli seperti Puzin, Rogé, Todorov, dan Djokosujatno.

Tabel Satuan Peristiwa-Peristiwa Fantastik

\begin{tabular}{ll}
\hline \multicolumn{1}{c}{ Cerita AMHJH } & \multicolumn{1}{c}{ Cerita AMBR } \\
\hline $\begin{array}{l}\text { Berubahnya seekor angkes menjadi seorang } \\
\text { pemuda yang tampan }\end{array}$ & $\begin{array}{l}\text { Dimasaknya daging ari-ari sebagai } \\
\text { pelampiasan rasa kesal tokoh istri terhadap } \\
\text { suaminya }\end{array}$ \\
\hline $\begin{array}{l}\text { Pembuatan jalan dari Baras Semanyang menuju } \\
\text { Sepang Simin yang selesai dalam waktu tiga } \\
\text { hari }\end{array}$ & $\begin{array}{l}\text { Burung Roak. } \\
\text { Berubahnya seekor ikan Tomang menjadi } \\
\text { seorang bayi perempuan }\end{array}$ \\
\hline $\begin{array}{l}\text { Tumbuhnya bayi jelmaan ikan menjadi seorang } \\
\text { gadis hanya dalam waktu beberapa bulan }\end{array}$ \\
$\begin{array}{l}\text { Berubahnya tulang belulang bayi manusia } \\
\text { menjadi tulang belulang binatang }\end{array}$ \\
\hline $\begin{array}{l}\text { Berkembangnya hantuen, makhluk jadi-jadian } \\
\text { penghisap darah dan dapat melepaskan diri dari } \\
\text { badannya }\end{array}$ \\
\hline
\end{tabular}




\section{SIMPULAN DAN SARAN}

Setelah pembahasan aspek kesastraan dan kefantastikkan dua cerita rakyat Kalimantan terdahulu, kini sampailah tulisan ini pada simpulan. Berikut adalah beberapa simpulan yang didapat.

Pertama, berdasarkan pengertian cerita fantastik yang disodorkan oleh Puzin, Rogé, Todorov, dan Djokosujatno, dua cerita rakyat Kalimantan yang terhimpun di dalam buku Kumpulan Cerita Rakyat Nusantara karya Kidh Hidayat yang berjudul Asal Mula Hantu Jadi-Jadian Hantuen (AMHJH) dan Asal Mula Burung Roak (AMBR), merupakan cerita fantastik. Ciriciri kefantastikkannya dapat dilihat pada satuan cerita fantastik. Kedua cerita ini memenuhi persyaratan cerita fantastik seperti cerita yang mengandung peristiwa atau sesuatu yang diciptakan oleh imajinasi, tidak terdapat di dunia nyata, ceritanya sangat tidak mungkin terjadi (Puzin, 1984: 3 dalam Ariani, 2007: 1). Kemudian persyaratan dari Todorov berikut, "keraguan pembaca adalah syarat utama cerita fantastik" (Todorov, 1970: 11-12 dalam Ariani, 2007:9).

Kedua, teori struktur karya Todorov yang digunakan untuk melihat aspek kesastraan cerita AMHJH dan AMBR, mengungkap bahwa cerita ini memiliki ciri kefantastikkan. Analisis aspek sintaksis karya mengungkap bahwa hubungan kausalitas cerita banyak mengandung peristiwa-peristiwa fantastik. Selain itu, analisis aspek semantik karya menemukan bahwa tokoh dan latar mengandung kefantastikkan.

Ketiga, struktur cerita fantastik Rogé yang digunakan untuk melihat aspek kefantastikkan dua cerita ini bisa diterapkan dan terungkaplah bahwa dalam dua cerita ini terdapat tahap ambition/keinginan, avertissement/peringatan, transgression/ pelanggaran, dan malédiction atau kutukan. Hal ini berarti dua cerita rakyat Kalimantan tersebut merupakan cerita fantastik.

Dari analisis yang dilakukan, peneliti memberikan beberapa saran untuk dapat menyempurnakan penelitian ini. Pertama, untuk lebih menyempurnakan aspek kesastraan dengan menggunakan teori struktural Todorov, aspek verbal dapat ditambahkan ke dalam pembahasan. Kedua, teori M.P. Schmitt dan A. Viala mengenai sekuen dapat pula ditambahkan untuk dapat mengetahui satuan-satuan teks cerita berupa sekuen.

Ketiga, untuk mengungkap aspek kefantastikkan, dapat pula ditekankan pada salah satu syarat cerita fantastik, semisal yang ditawarkan Todorov yaitu keraguan pembaca.

\section{PUSTAKA RUJUKAN}

Ariani, A. (2007). Ciri-Ciri Fantastik dalam "Le Horla" Karya Guy De Maupassant. Skripsi. Depok: Program Studi Perancis Universitas Indonesia.

Danandjaja, J. (2007). Folklore Indonesia: Ilmu Gosip, Dongeng, dan lain-lain. Jakarta: Pustaka Utama Grafiti.

Djokosujatno. A. (2001). "Kata Pengantar" dalam Djokosujatno (penerjemah). Empat Cerita Fantastik Perancis. Jakarta: YOI.

Durachman, M. (1996). Khotbah di Atas Bukit, Novel Gagasan Karya Kuntowijoyo. Tesis. Depok: Program Studi Ilmu Susastra Universitas Indonesia.

Hidayat, K. (1999). Kumpulan Cerita Rakyat Nusantara. Surabaya: CV. Pustaka Agung Harapan

Todorov, T. (1985). Tata Sastra. Jakarta: Penerbit Djambatan.

Zaimar, Okke K.S. (2008). "Metodologi Penelitian Sastra Lisan" dalam Pudentia (Ed). Metodologi Kajian Tradisi Lisan. Jakarta: Asosiasi Tradisi Lisan.

\section{UCAPAN TERIMA KASIH}

Peneliti mengucapkan banyak terima kasih kepada semua pihak yang telah membantu menyelesaikan tulisan ini sehingga dapat selesai tepat waktu. Ucapan terima kasih secara khusus peneliti sampaikan kepada: 
1) Drs. Memen Durachman, M.Hum., yang telah memberikan saran untuk istikharah dalam pemilihan peminatan dan telah banyak memberikan diskusi mengenai folklor walau pun itu di luar jam perkuliahan.

2) Yulianeta, M.Pd., untuk biaya penelitian yang secara ikhlas beliau berikan sebagai hadiah untuk peneliti dan diskusi sederhana penuh makna tentang sastra.
3) Rekan-rekan Nonkependidikan A Bahasa dan Sastra Indonesia 2011, Kelas Sastra 2011, terutama untuk Akbar, Agus, Bendhawer, Bunga, Asep, dan Adi, untuk semangat yang mereka tularkan pada peneliti. 